\title{
Optimization of lipase synthesis by Mucor racemosus - Production in a triple impeller bioreactor
}

\author{
Nadia, N., ${ }^{1}$ Nehad, Z. A., ${ }^{\star}$ Elsayed, A. E., ${ }^{2}$ Essam, M. A. ${ }^{1}$ and Hanan, M. A. ${ }^{1}$ \\ ${ }^{1}$ Chemistry of Natural and Microbial Product Department, National Research Centre, Dokki, Cario, Egypt. \\ ${ }^{2}$ Program of Chemical Engineering COPPE, Federal University of Rio de Janeiro, Caixa, Rio de Janeiro/RJ, Brazil. \\ E-mail: nehadhnrc@yahoo.com
}

Received 24 March 2009; received in revised form 11 May 2009; accepted 31 May 2009

\begin{abstract}
Fungal cultures were screened for their ability to produce extracellular lipase through different incubation periods, in spite of some Aspergillus niger gave highest lipolytic activities, Mucor racemosus was selected in this study due to its non-pathogenicity. Optimum lipase activity was obtained after 3 days incubation period at $35{ }^{\circ} \mathrm{C}$ using submerged culture technique. Using a modified complex medium (3\% peptone; $0.2 \% \mathrm{KH}_{2} \mathrm{PO}_{4} ; 0.05 \% \mathrm{KCl} ; 0.05 \% \mathrm{MgSO}_{4} \cdot 7 \mathrm{H}_{2} \mathrm{O} ; 1 \%$ glucose; $1 \%$ olive oil and $0.01 \mathrm{M}$ barium acetate as additives; $\mathrm{pH}$ was adjusted to 7.0 using $0.2 \mathrm{M}$ phosphate buffer) stimulated $M$. racemosus lipase by $114.3 \%$. The production of lipolytic enzyme by $M$. racemosus was up-scaled to $5 \mathrm{~L}$ stirred-tank bioreactor. Under optimized conditions, lipase and specific enzyme activities were improved by 2 folds (1211 $\mathrm{U} / \mathrm{mL}$ and $28 \mathrm{U} / \mathrm{mg}$ protein) as compared to shake flask studies.
\end{abstract}

Keywords: lipase, Mucor racemosus, culture conditions, fermentation, bioreactor

\section{INTRODUCTION}

Lipases (Triacylglycerol acylhydrolases; EC 3.1.1.3) are versatile and ubiquitous biocatalysts with a wide range of application. Microbial lipases are commercially important because of their unique properties and the ease of their bulk extracellular production, compared to lipases from other natural sources (Jaeger and Eggert, 2002). The interest in microbial lipase production has increased in the last decades, because of its large potential in industrial applications as additives for foods (flavor modification), fine chemicals (synthesis of esters), waste water treatment (decomposition and removal of oil substances), cosmetics (removal of lipids), pharmaceuticals (digestion of oils and fats in foods), leather (removal of lipids from animal skins) and medical (blood triglyceride assay) (Davranov, 1994; Pandey et al., 1999; Burkert et al., 2004; Kumar et al., 2005).

Lipase production is dependent upon a number of factors including carbon and nitrogen sources, $\mathrm{pH}$, temperature, aeration and inoculum size (Kim et al., 1996; Gupta et al., 2004). Fungal lipases are typically produced in submerged cultures using complex culture media whose ingredients include vitamins, organic salts, amino acids and complex sources of organic compounds, such as yeast extract, peptone, soy meal and corn-steep liquor (Sarkar et al., 1998; Chahinian et al., 2000; Sharma et al., 2001; Lin and Ko, 2005). Fungal lipases have a pH optimum in the neutral or slightly acid range. Elwan et al. (1986b) studied lipases from Aspergillus sydowi and found that, the optimum $\mathrm{pH}$ value varied greatly with variation in the buffer system used. Also temperature is considered one of the most important factors and it varied greatly with different strains, for example, optimal temperature for Acinetobacter radioresistens was $30{ }^{\circ} \mathrm{C}$ when cultivated on $2.5 \mathrm{~L}$ tank fermentor ( $\mathrm{Li}$ et al., 2005), $37^{\circ} \mathrm{C}$ for Burkholderia multivorans (Gupta et al., 2007), $55^{\circ} \mathrm{C}$ for thermophilic bacterium Bacillus coagulans (Kumar et al., 2005). Several researchers found that, aeration increased lipase accumulation (Sugiura et al., 1977; Gupta et al., 2004). But the extent of aeration optimal is not the same for different producers.

The extensive application of lipolytic enzymes as industrial biocatalysts requires the development of largescale processes for their production. Recently attention was directed to the production of lipases under large scale fermentations and at different aeration and agitation rates (Tan et al., 2003, Gupta et al., 2007).

Despite the presence of a large number of already discovered and characterized lipolytic enzymes, the search for new lipase producers remains important due to the wide range of practical industrial application. The aim of the present work was to determine the optimum parameters favorable for the growth and lipase production of Mucor racemosus using shake flasks studies. Then process variables have been used in a $5 \mathrm{~L}$ bioreactor for the fermentation process to obtain high lipase production.

\section{MATERIALS AND METHODS}

\section{Microorganisms}

The following microbial strains were screened for lipase activity: Aspergillus niger oil (isolated from oil), A. niger 
$102 \mathrm{H}$, A. niger $16 \mathrm{H}$, A. niger $7 \mathrm{H}$. A.carneus. A. flavus, $A$ fumari, $A$. fumigatus, $A$. niveus, $A$. terreus $1 \mathrm{H}, A$. terreus $2 \mathrm{H}$, A. terreus $3 \mathrm{H}$, A.wentii, Botrytis sp., Cunninghamella sp., Fusarium. clomydo, F. solani, Fusarium sp., Mucor hiemalis, M. pusillus, M. racemosus, M. roxii NRRL1894, Penicillium cyclopium, $P$. duclauxi, $P$. funiculosum, Rhizoctonia sp., Rhizopus sp., Sclerotium sp. Trichoderma viride. Microbial cultures were obtained from Microbiology Research Centre, Ain Shams University (MIRCEN); Botany Department, Faculty of Girls, Ain Shams University (BDFGASU); National Centre for Radiation Research and Technology (NCRRT); National Research Centre (NRC); Cairo, Egypt and the culture collection of Northern Regional Research Laboratory (NRRL), USA. The organisms were subcultured on potato dextrose agar for 7 days at $30^{\circ} \mathrm{C}$. The spore crop of each slant was scrapped in $5 \mathrm{~mL}$ sterile water. A spore suspension of about $8.75 \times 10^{7} / \mathrm{mL}$ was used as a source of inoculum.

\section{Lipase production}

Five different cultivation media were evaluated for the production of lipase enzyme. The composition of the different fermentation media can be summarized as follows:

Medium I: $3.0 \%$ peptone; $0.2 \% \quad \mathrm{KH}_{2} \mathrm{PO}_{4} ; 0.05 \% \mathrm{KCl}$ $0.05 \% \mathrm{MgSO}_{4} \cdot 7 \mathrm{H}_{2} \mathrm{O}$ and $1 \%$ olive oil: glucose $(0.5: 0.5)$, pH 6.6 (Akhtar et al., 1980).

Medium II: $0.1 \% \quad \mathrm{NH}_{4} \mathrm{NO}_{3} ; \quad 0.2 \% \quad \mathrm{KH}_{2} \mathrm{PO}_{4} ; \quad 0.04 \%$ $\mathrm{MgSO}_{4} \cdot 7 \mathrm{H}_{2} \mathrm{O} ; 0.1 \% \mathrm{FeSO}_{4} .7 \mathrm{H}_{2} \mathrm{O} ; 1.0 \%$ sucrose and $1.0 \%$ olive oil (Pal et al., 1978).

Medium III: $1.2 \% \quad \mathrm{NaH}_{2} \mathrm{PO}_{4} ; \quad 0.2 \% \quad \mathrm{KH}_{2} \mathrm{PO}_{4} ; \quad 0.03 \%$

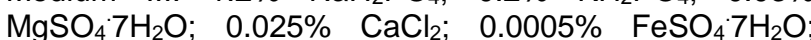
$0.0015 \% \mathrm{MnSO}_{4} \cdot 7 \mathrm{H}_{2} \mathrm{O} ; 0.003 \% \mathrm{ZnSO}_{4} \cdot 7 \mathrm{H}_{2} \mathrm{O} ; 2 \%$ corn oil and $1 \%$ peptone, pH 5.5 (Hatzinikolaou et al., 1996).

Medium IV: $1.0 \%$ peptone; $6.48 \%$ soybean waste; $0.2 \%$ $\mathrm{KH}_{2} \mathrm{PO}_{4} ; 0.05 \% \mathrm{KCl} ; 0.05 \% \quad \mathrm{MgSO}_{4} \cdot 7 \mathrm{H}_{2} \mathrm{O}$ and $0.5 \%$ Arabic gum, pH 6.0 (Abdel-Aal, 1996).

Medium V: $3 \%$ peptone; $7.0 \%$ cotton seed waste; $0.2 \%$ $\mathrm{KH}_{2} \mathrm{PO}_{4} ; 0.05 \% \mathrm{KCl} ; 0.05 \% \quad \mathrm{MgSO}_{4} \cdot 7 \mathrm{H}_{2} \mathrm{O}$ and $0.5 \%$ Arabic gum, pH 6 (Ahmed, 2000).

After preparation, the $\mathrm{pH}$ values of the prepared media were initially adjusted (5.5-6.6) before being sterilized by autoclaving for $15 \mathrm{~min}$ at a pressure of $1.5 \mathrm{lb} / \mathrm{inch}^{2}$. Unless otherwise stated, the tested microorganisms were grown in $250 \mathrm{~mL}$ flasks containing $50 \mathrm{~mL}$ of the cultivation media and incubated at $30^{\circ} \mathrm{C}$ on a reciprocal shaker $(200$ $\mathrm{rpm}$ ) for 2, 3 and 4 days incubation periods. At the end of the cultivation, the biomass was harvested by filtration through a dried, pre-weighted filter paper and thoroughly washed with distilled $\mathrm{H}_{2} \mathrm{O}$, then dried in oven at $70{ }^{\circ} \mathrm{C}$ until complete dryness and then reweighed. The level of extracellular lipase was assayed according to lipase activity in the supernatant.

\section{Determination of lipase activity}

Lipase activity was determined according to the method described by Parry et al. (1966) using an emulsion of $10 \%$ olive oil in $10 \%$ gum Arabic. The emulsion produced by treating the mixture of olive oil and gum Arabic solution in a top drive homogenizer for $10 \mathrm{~min}$. The reaction mixture contained $3 \mathrm{~mL}$ of substrate (emulsion), $2.5 \mathrm{~mL}$ of deionized water, $1 \mathrm{~mL}$ of $0.2 \mathrm{M}$ Tris- $\mathrm{HCl}$ buffer $(\mathrm{pH} 7.5)$ and $1.0 \mathrm{~mL}$ lipase sample. The reaction mixture was then supplemented with $10 \mathrm{~mL}$ ethanol. The reaction was carried out at $37{ }^{\circ} \mathrm{C}$ for $2 \mathrm{~h}$ in shaking water bath. The amount of oleic acid produced was determined by titrating the hydrolysis products with $0.05 \mathrm{~N} \mathrm{NaOH}$ using thymolphthalein indicator. The control sample was prepared and treated similarly using boiled enzyme samples. The lipase activity values were calculated as the average of three parallel determinations displaying a variation coefficient lower than $5 \%$. The amount of enzyme catalyzing the formation of one micro-equivalent (micromole) of oleic acid in $2 \mathrm{~h}$ at $37^{\circ} \mathrm{C}$ and $\mathrm{pH} 7.5$ was taken as one lipase activity unit.

$1 \mathrm{U} / \mathrm{mL}=$ formation of $\mathrm{U}$ mol free fatty acids $/ 1 \mathrm{~mL}$ enzyme solution.

The protein determination was carried out by the method of Lowry et al. (1951).

\section{Determination of glucose}

Glucose was determined according to the method of Passing and Beblox (1983). A $10 \mu \mathrm{L}$ of sample $+1 \mathrm{~mL}$ glucose oxidase kits (GOD) was incubated at $37^{\circ} \mathrm{C}$ for 15 min. The produced color was measured at $520 \mathrm{~nm}$. A standard curve was prepared using a pure glucose standard solution.

\section{Toxicity test of Mucor racemosus}

One hundred $\mathrm{mL}$ of YES medium (2\% yeast extract and $15 \%$ sucrose) were inoculated with spore suspension of $M$. racemosus strain, incubated in dark for 14 days at $25^{\circ} \mathrm{C}$. Extraction of mycotoxins was carried out according to Munimbazi and Bullerman (1998). Aflatoxins ( $B_{1}, B_{2}, G_{1}$ and $G_{2}$ ) were determined by HPLC according to the method of Deabes et al. (2007).

\section{Response of some additives}

In the present experiment, the lipase activities were investigated when $M$. racemosus was cultivated on the basal medium at its optimal fermentation parameters and fortified with inducible additives including representative of trace elements, fatty acids, amino acids and vitamins. The modified basal medium contained (\% w/v): peptone, 3; glucose, 1.0; olive oil, $1.0 ; \mathrm{KH}_{2} \mathrm{PO}_{4}, 0.2 ; \mathrm{KCl}, 0.05$; $\mathrm{MgSO}_{4} \cdot 7 \mathrm{H}_{2} \mathrm{O}, 0.05, \mathrm{pH}$ of the medium adjusted by phosphate buffer $(\mathrm{pH} 7)$. The fermentation medium was incubated for 3 days at $35{ }^{\circ} \mathrm{C}$ using shaking technique. Relative activity $\%=$ activity of sample /activity of control (without additives) x 100 . 


\section{Lipase production in $5 \mathrm{~L}$ stirred tank bioreactor}

M. racemosus lipase was produced using in 5 L-stirred tank bioreactor Bio Flow 3000 (New Brunswick Scientific, $\mathrm{NJ}$, USA). The bioreactor vessel contained $3.5 \mathrm{~L}$ working volume of the optimized fermentation medium: $3 \%$ peptone; $2 \%$ (glucose: olive oil 1:1); $0.2 \% \mathrm{KH}_{2} \mathrm{SO}_{4} ; 0.05 \%$ $\mathrm{KCl} ; 0.05 \% \mathrm{MgSO}_{4} \cdot 7 \mathrm{H}_{2} \mathrm{O} ; 0.01 \mathrm{M}$ barium acetate and $4 \%$ spore suspension (8.75 x 10 7 spores).

The bioreactor was equipped with a three 4-bladed rushton turbine impeller diameter (di), $65 \mathrm{~mm}$; tank diameter (dt), $135 \mathrm{~mm}$, dt:di, 1: 0.48. The optimized medium was sterilized at $121^{\circ} \mathrm{C}$ for $30 \mathrm{~min}$. Glucose and phosphate buffer solutions $(\mathrm{pH} 7.0)$ were sterilized separately and were mixed aseptically with other components of the medium in the bioreactor upon inoculation. The medium was inoculated with $4 \%(\mathrm{v} / \mathrm{v})$ spore suspension $\left(8.75 \times 10^{7} / \mathrm{mL}\right)$ and fermentation was carried out at $35{ }^{\circ} \mathrm{C}$ at $\mathrm{pH} 7.0$. The impeller speed was adjusted to $300 \mathrm{rpm}$. The aeration was adjusted at $1 \mathrm{v} / \mathrm{v} / \mathrm{m}$. Samples were taken from the bioreactor every $12 \mathrm{~h}$ and analyzed for lipase activity, protein concentration, residual sugar and biomass estimation.

\section{RESULTS AND DISCUSSION}

\section{Screening of lipase activity}

The production of extracellular lipase varied not only with the type of the culture used but also by its species at different cultivation periods. Therefore among 29 different fungal species, 26 species of these cultures manifested large variation in its capacity to produce lipases (Table 1). We choose $M$. racemosus although its activity is less than that of $A$. niger (oil), because it is not pathogenic and more safe than the other Aspergilli. Toxicity test was performed to confirm this selection, the result is negative and alfatoxins not detect.

There is literature review full with production of lipases by different species of Mucor (Hiol et al., 2000; Abbas et al., 2002). According to our knowledge there is no reference concerning $M$. racemosuss lipases. This finding with the toxicity test result justified its selection as a potent organism for lipases production.

\section{Optimization of lipase production by $M$. racemosus}

Five different media were used for lipase production by $M$. racemosus. The results in Figure 1 showed that medium I gave the maximum production $(337.6 \mathrm{U} / \mathrm{mL})$ with specific enzyme activity $7.3 \mathrm{U} / \mathrm{mg}$. Medium IV shows moderate production of lipase $(295.0 \mathrm{U} / \mathrm{mL})$. Some authors stated that, lipase production greatly affected by the composition of the medium (Lin and Ko, 2005; Rodriguez et al., 2006). Sarkar et al. (1998) stated that lipase production is enhanced in complex culture medium than in a simple one.
Table 1: Screening of fungi for lipase production

\begin{tabular}{|c|c|c|c|}
\hline \multirow[t]{2}{*}{ Microorganisms } & \multicolumn{3}{|c|}{ Lipase activity (U/mL) } \\
\hline & 2 days & 3 days & 4 days \\
\hline Aspergillus niger (oil) & 535.0 & 455.0 & 435.0 \\
\hline A. niger $102 \mathrm{H}$ & 180.0 & 145.0 & 175.0 \\
\hline A. niger $16 \mathrm{H}$ & 275.0 & 239.7 & 153.0 \\
\hline A. niger $7 \mathrm{H}$ & 270.0 & 210.0 & 175.0 \\
\hline A. carneus & 50.0 & 32.9 & 80.0 \\
\hline A. flavus & 25.0 & 95.0 & 0.0 \\
\hline A. fumari & 30.0 & 85.0 & 45.0 \\
\hline A. fumigates & 32.9 & 40.0 & 20.0 \\
\hline A. niveus & 0.0 & 80.0 & 40.0 \\
\hline A. terreus $1 \mathrm{H}$ & 120.0 & 225.0 & 15.0 \\
\hline A. terreus $2 \mathrm{H}$ & 175.0 & 215.0 & 135.0 \\
\hline A. terreus $3 \mathrm{H}$ & 0.0 & 10.0 & 0.0 \\
\hline A.wentii & 265.0 & 193.0 & 20.4 \\
\hline Botrytis sp. & 80.0 & 20.4 & 40.8 \\
\hline Cunninghamella sp. & 0.0 & 15.0 & 0.0 \\
\hline Fusarium clamydo & 0.0 & 0.0 & 0.0 \\
\hline Fusarium solani & 0.0 & 0.0 & 0.0 \\
\hline Fusarium sp. & 0.0 & 0.0 & 0.0 \\
\hline Mucor hiemalis & 95.0 & 185.0 & 250.0 \\
\hline M. pusillus & 100.0 & 240.0 & 50.0 \\
\hline M. racemosus & 220.0 & 337.6 & 175.0 \\
\hline M. roxii NRRL1894 & 72.0 & 130.0 & 47.0 \\
\hline Penicillium cyclopium & 45.0 & 96.9 & 70.0 \\
\hline P. duclauxi & 25.0 & 75.0 & 0.0 \\
\hline P.funiculosum & 19.2 & 185.1 & 71.4 \\
\hline Rhizoctonia sp. & 90.0 & 80.0 & 40.8 \\
\hline Rhizopus sp. & 25.0 & 90.0 & 35.0 \\
\hline Sclerotium sp. & 50.0 & 35.0 & 0.0 \\
\hline Trichoderma viride. & 0.0 & 15.0 & 0.0 \\
\hline
\end{tabular}

*Production medium used: medium I (see materials and methods)

The physiological studies were started by studying the effect of inoculum size. The lipase activity of the experimental organism was gradually increased by increasing the inoculum size $(2-4 \mathrm{~mL} / 100 \mathrm{~mL}$ medium) to reach the maximum at $4 \mathrm{~mL}\left(8.75 \times 10^{7}\right.$ spores $\left./ \mathrm{mL}\right)$ and then decreased gradually by increasing of the inoculum size (data not shown). The fungal activity was tested using surface and the submerged culture techniques each was investigated under different incubation periods (1-5 days).

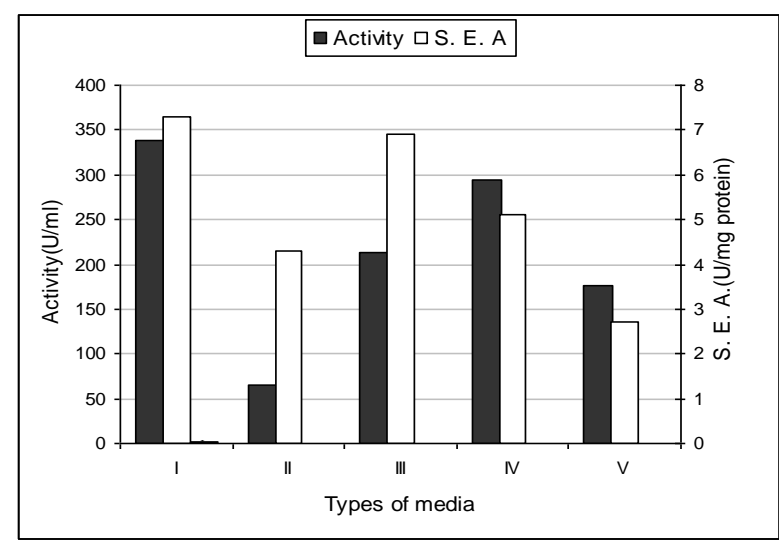

Figure 1: Production of Mucor racemosus lipase using different media 
The submerged (shacked culture) technique affords high lipase production with the highest lipolytic activities (337.6 $\mathrm{U} / \mathrm{mL}$ ) after 3 days of incubation. After $48 \mathrm{~h}$ the productivity in submerged technique $(6.7 \mathrm{U} / \mathrm{mL}$.h) was higher than that of the static with about 42 fold. This may be attributed to the fact that submerged technique allowed better emulsification of the lipids (olive oil) and also good aeration (Table 2). The maximal production of lipase and S. E. A. (395.2 U/mL and $8.3 \mathrm{U} / \mathrm{mg}$ protein) were obtained at $35^{\circ} \mathrm{C}$ (Figure 2). These results agreed with Silva et al. (2005) who reported that the best temperature in the basal medium for Metarhizium anisophiae lipase production was $32^{\circ} \mathrm{C}$. There was a sharp decrease in lipase activity $(89.8$ $\mathrm{U} / \mathrm{mL}$ ) at $45^{\circ} \mathrm{C}$ and this may be attributed to the denaturation of enzyme.

The tested fungus $M$. racemosus was separately cultivated on buffered medium using different buffer at different $\mathrm{pH}$ (Table 3). Maximum lipase activity (485.0 $\mathrm{U} / \mathrm{mL}$ ) and S. E. A. (10.1 U/mg protein) were obtained by $0.2 \mathrm{M}$ phosphate buffer at $\mathrm{pH}$ 7.0. As a general, good lipase production was obtained in all buffered medium $\mathrm{pH}$ 4-7) after 3 days incubation. Low lipase production was obtained at alkaline $\mathrm{pH}$. These results agree those obtained by many investigators, Abdel-Fatah and Hammad (2002) claimed that increasing $\mathrm{pH}$ over 6 decrease lipase produced by the tested filamentous fungi. In addition, Elwan et al. (1986a) reported that the amount of lipase produced by Penicillium crysogenum was markedly reduced over $\mathrm{pH}$ 7.0. Therefore, we can say that the optimum $\mathrm{pH}$ values were greatly dependent on the culture conditions as well as the type of the buffer used. Also lipase activity using optimum buffered $\mathrm{pH}$ $(485.0 \mathrm{U} / \mathrm{mL})$ was higher than that using optimal initial $\mathrm{pH}$ (395.2 U/mL, data not shown) with 1.23 fold. This is in agreement with Ammar (1983) and Elwan et al. (1986 a). Silva et al. (2005) used buffered medium with $0.1 \mathrm{M}$ sodium phosphate buffer in the following $\mathrm{pH}: 5.7,6.3$ and 8.0. They observed that, the best lipase production by $M$. anisophiae was obtained when the medium was buffered with $\mathrm{pH}$ 5.7. Minning et al. (2001) used $100 \mathrm{mM}$ potassium phosphate buffer pH 6.0 in the culture medium for high level production of Rhizopus oryzae lipase. M. racemosus extracellular lipase was highly affected by the nature of the carbon source used. Lowest lipase activity obtained using glucose as a sole carbon source (Table 4). Olive oil as a sole carbon source increased lipase activity (377.40 $\mathrm{U} / \mathrm{mL}$ ) but maximal yields of lipase by using mixture of glucose:olive oil (0.5:5 wt\%). These indicated that $M$. racemosus lipase is inductive enzyme and olive oil was effective in inducing enzyme formation and the organism needed glucose and olive oil both together for high lipases production. These results were confirmed with Destain et al. (2005) who reported that olive oil in combination with glucose was used as the carbon source and inducer for the production of lipase. Also Maia et al. (2001) and Li et al. (2005) concluded that the production of microbial lipases generally needs a fat-related carbon source. In attempts to optimize the concentration of both glucose and olive oil show that increasing glucose and olive oil concentration up to $1 \%$ gave maximum lipolytic activity
556.0 U/mL (Figure 3 and 4). Higher levels of glucose and olive oil gave a deleterious effect on lipase production in spite of biomass stimulation in olive oil treatment.

Table 2: Effect of cultivation methods and incubation period on lipase activity and productivity by $M$. racemosus

\begin{tabular}{ccccc}
\hline \multirow{2}{*}{$\begin{array}{c}\text { ime } \\
\text { (h) }\end{array}$} & $\begin{array}{c}\text { Lipase } \\
\text { activity } \\
\text { U/mL }\end{array}$ & $\begin{array}{c}\text { Productivity } \\
\text { U/mL/h }\end{array}$ & $\begin{array}{c}\text { Lipase } \\
\text { activity } \\
\text { U/mL }\end{array}$ & $\begin{array}{c}\text { Productivity } \\
\text { U/mL/h }\end{array}$ \\
\hline 24 & 92.02 & 3.83 & 0.0 & 0.00 \\
48 & 322.05 & 6.71 & 27.0 & 0.16 \\
72 & 337.60 & 4.68 & 0.0 & 0.00 \\
96 & 260.70 & 2.71 & 0.0 & 0.00 \\
120 & 199.40 & 1.66 & 0.0 & 0.00 \\
\hline
\end{tabular}

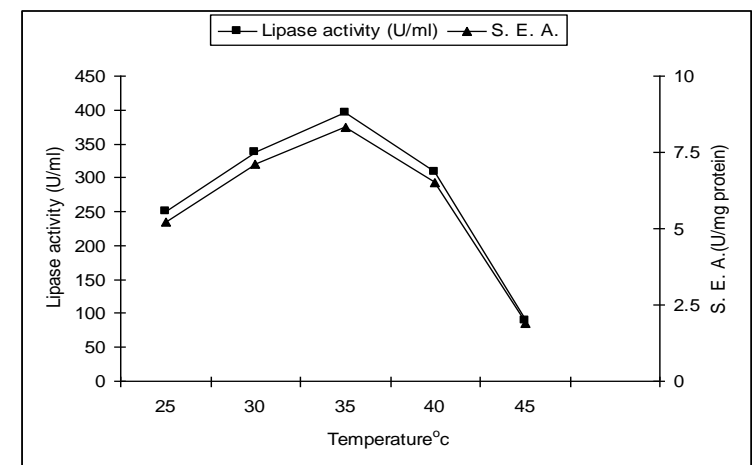

Figure 2: Effect of incubation temperature on lipase production by Mucor racemosus

Table 3: Effect of different buffered $\mathrm{pH}$ medium on lipase activity and S. E. A. by M. racemosus

\begin{tabular}{ccccc}
\hline $\begin{array}{c}\text { Buffer } \\
\text { Type }\end{array}$ & $\begin{array}{c}\text { Final } \\
\text { pH }\end{array}$ & $\begin{array}{c}\text { Lipase } \\
\text { activity } \\
\text { (U/mL) }\end{array}$ & $\begin{array}{c}\text { S.E.A. } \\
\text { (U/mg } \\
\text { protein) }\end{array}$ & $\begin{array}{c}\text { Relative } \\
\text { activity } \\
(\%)\end{array}$ \\
\hline $\begin{array}{c}\text { Citrate-phosphate } \\
\text { buffer }\end{array}$ & & & & \\
4.0 & 4.20 & 235.8 & 4.90 & 59.66 \\
5.0 & 5.20 & 248.6 & 5.20 & 62.90 \\
6.0 & 5.56 & 255.0 & 5.31 & 64.52 \\
7.0 & 7.30 & 121.0 & 2.50 & 30.62 \\
Phosphate buffer & & & & \\
6.5 & 6.20 & 379.1 & 7.90 & 95.93 \\
7.0 & 6.90 & 485.0 & 10.10 & 122.72 \\
7.5 & 7.00 & 405.0 & 8.44 & 102.48 \\
8.0 & 7.60 & 282.7 & 5.90 & 71.53 \\
Tris-buffer & & & & \\
7.5 & 6.50 & 266.7 & 5.50 & 67.48 \\
8.0 & 7.60 & 240.0 & 5.00 & 60.73 \\
8.5 & 7.70 & 186.3 & 3.90 & 47.14 \\
9.0 & 8.70 & 115.6 & 2.40 & 29.25 \\
\hline
\end{tabular}

${ }^{*}$ Relative activity $\%$ = activity of sample /activity of control X100 Control $=(395.2 \mathrm{U} / \mathrm{mL}$ at optimal $\mathrm{pH})$ 
Table 4: Effect of glucose and olive oil as a carbon sources

\begin{tabular}{lc}
\hline Carbon source 1\% (w/v) & Lipase activity(U/mL) \\
\hline Glucose & 267.75 \\
Olive oil & 377.40 \\
Glucose + Olive oil (control) & 485.00 \\
\hline
\end{tabular}

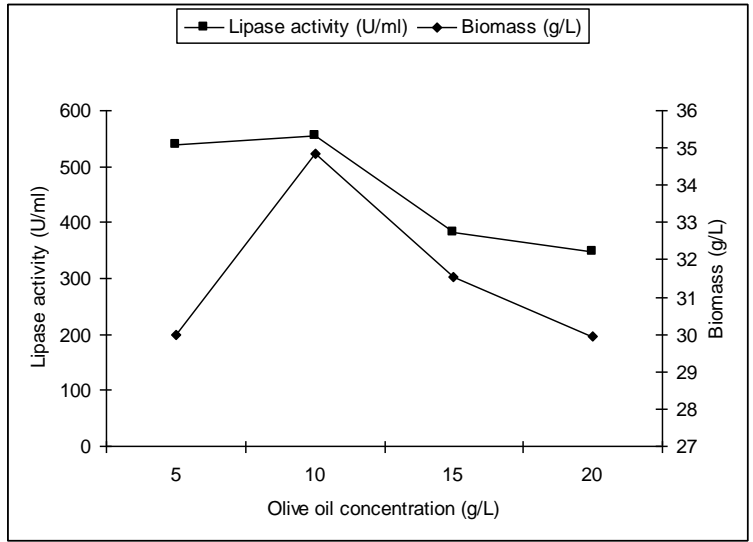

Figure 3: Effect of different concentration of glucose on biomass and lipase activity (concentration of olive oil $0.5 \%$ )

Our results were confirmed by Lin and Ko (2005) who reported that higher levels of glucose in the medium displayed an inhibitory effect on Antrodia cinnamonae lipase production. Furthermore, lipase activities of many other fungi such as Aspergillus wentii (Chander et al., 1980); Mucor hiemalis (Akhtar et al., 1980) and Bukholderia (Rathi et al., 2001) are stimulated by the addition of glucose to the production media. The lower production of lipase by increasing olive oil concentrations may be due to the inhibition effect of the fatty acid (oleic acid) in the culture medium as result of olive oil hydrolysis (Akhtar et al., 1980).

The most suitable nitrogen for lipase production by the experimental fungus proved to be peptone (Figure 5). All the tested nitrogen sources (organic and inorganic) caused a decrease in lipase production. Freire et al. (1997) and Rodriguez et al. (2006) found peptone to give the best results for lipase production. Freire et al. (1997) assumed that peptone contains certain co-factors and amino acids which match physiological requirement for lipase biosynthesis.

\section{Response of some additives}

Results of this investigation was illustrated in Table 5.On the tested trace elements as acetate, the enzyme was favorably affected, stimulated (114.3 \& 100.8\%) by $\mathrm{Ba}^{2+}$ and $\mathrm{K}^{+}$and inhibited by $\mathrm{Na}^{+}$on the tested trace elements as sulphates, also the enzyme was favorably affected, stimulated (111.2 \& 106.1\%) by $\mathrm{Li}^{+}$and $\mathrm{Na}^{+}$but inhibited (86.8-76.6\%) by $\mathrm{Zn}^{2+}, \mathrm{Fe}^{++}$. Sugiura (1984) and
Iwai and Tsujisaka (1984) recorded that the mechanism of which the metal ions influence the lipase production is

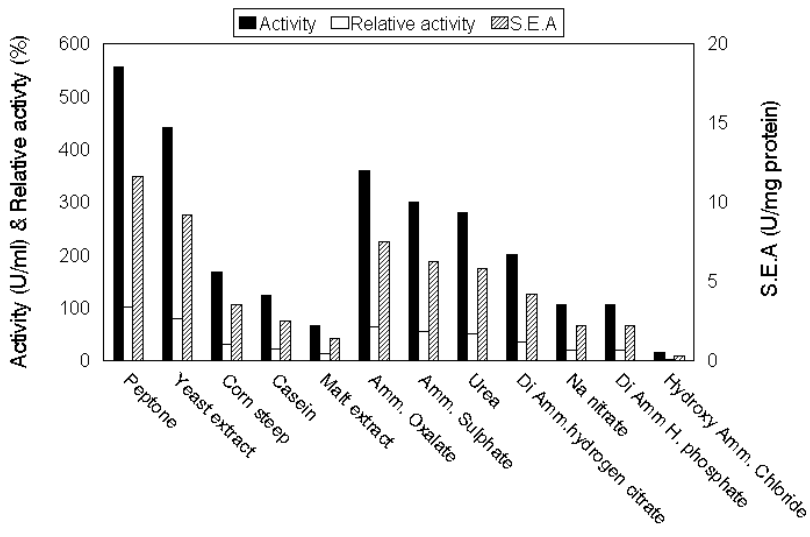

Nitrogen sources

Figure 5: Effect of different nitrogen sources on lipase production by $M$. racemosus

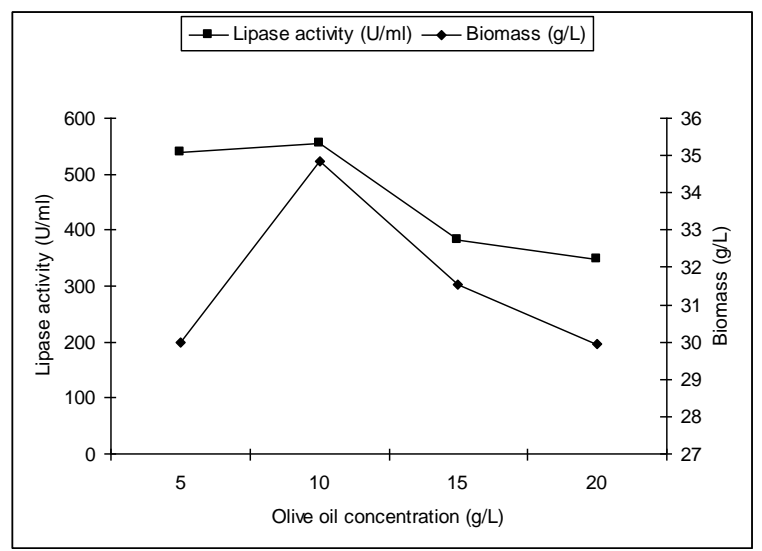

Figure 4: Effect of different concentration of olive oil on biomass and lipase activity (concentration of glucose $1 \%$ )

unknown. From our result we conclude that, the same ion exhibited different biochemical activities specific for each microorganism and it may be changed owing to the salt employed. Thus $\mathrm{Na}^{+}$exerted an inhibitory (as carbonate and acetate) and activatory (as sulphate).

The tested fatty acids proved to be conductive for lipase production, both saturated (palmitic) and unsaturated (oleic acid) fatty acid caused increasing on lipase production at all concentrations (except $100 \mathrm{mg}$ oleic). These results were agreed with Pokorny et al. (1994), Long et al. (1996), Dalmau et al. (2000) and Li et al. (2005) reported that lipase synthesis is known to be repressed by high concentration of oleic acid. Tween 20 and 80 had inhibitory effects (54.7-31.4\%) on the lipolytic activities at all levels Table 5 . These results were similar to those of Prazeres et al. (2006) who found that Tween 40, Tween 80 inhibited up to $30 \%$ of Fusarium oxysporum lipase activity. $M$. racemosus lipase was negatively 
responded to the added amino acid. Glutamic acid had a maximum inhibitory effect $(29.4 \%)$. These results agreed with Litchfield and Prescott (1970) and Fernandez et al. (1990) who showed that there were a repression of extracellular Aeromonas proteolytica and Pseudomonas fluorescens lipase, respectively by amino acids. On studying the addition of different concentrations of some vitamins to the fermentation medium we found that the optimum concentration $(0.1,0.1$ and $0.75 \mathrm{mg} / 100 \mathrm{~mL})$ of ascorbic acid, folic acid and becofort respectively giving stimulatory effects (108.10, 107.47 and $103.73 \%$ respectively). Minning et al. (2001) used biotin in the,

Table 5: Response of some additives on lipase activity

\begin{tabular}{|c|c|c|}
\hline Concentration & Additives & $\begin{array}{l}\text { Relative } \\
\text { activity \% }\end{array}$ \\
\hline \multirow{10}{*}{$\begin{array}{l}\text { Metal salts } \\
(0.01 \mathrm{M})\end{array}$} & Barium acetate & 114.3 \\
\hline & Sodium acetate & 44.7 \\
\hline & Potassium acetate & 100.8 \\
\hline & Sodium carbonate & 40.0 \\
\hline & Manganesesulphate & 80.3 \\
\hline & Zinc sulphate & 13.2 \\
\hline & Lithium sulphate & 111.2 \\
\hline & Ferrous sulphate & 23.4 \\
\hline & Ferric sulphate & 19.3 \\
\hline & Sodium sulphate & 106.1 \\
\hline \multirow{8}{*}{$\begin{array}{l}\text { Fatty acids } \\
(\mathrm{mg} / 100 \mathrm{~mL})\end{array}$} & Palmitic acid, $25 \mathrm{mg}$ & 103.1 \\
\hline & Palmitic acid, 50mg & 105.9 \\
\hline & Palmitic acid, $75 \mathrm{mg}$ & 109.3 \\
\hline & Palmitic acic, $100 \mathrm{mg}$ & 104.2 \\
\hline & Oleic acid, $25 \mathrm{mg}$ & 110.8 \\
\hline & Oleic acid, $50 \mathrm{mg}$ & 111.8 \\
\hline & Oleic acid, $75 \mathrm{mg}$ & 100.8 \\
\hline & Oleic acid, $100 \mathrm{mg}$ & 94.8 \\
\hline \multirow{6}{*}{$\begin{array}{l}\text { Tweens } \\
(\mathrm{mg} / 100 \mathrm{~mL})\end{array}$} & Tween $20,50 \mathrm{mg}$ & 61.9 \\
\hline & Tween $20,75 \mathrm{mg}$ & 66.3 \\
\hline & Tween 20,100mg & 58.9 \\
\hline & Tween $80,50 \mathrm{mg}$ & 68.6 \\
\hline & Tween $80,75 \mathrm{mg}$ & 46.4 \\
\hline & Tween $80,100 \mathrm{mg}$ & 45.3 \\
\hline \multirow{5}{*}{$\begin{array}{l}\text { Amino acids } \\
(\mathrm{mg} / 100 \mathrm{~mL})\end{array}$} & Leucine, $1 \mathrm{mg}$ & 96.5 \\
\hline & Tyrosine, $1 \mathrm{mg}$ & 93.41 \\
\hline & Asparagine, $1 \mathrm{mg}$ & 91.4 \\
\hline & Glutamic, 1mg & 70.59 \\
\hline & Arjinine, $1 \mathrm{mg}$ & 82.30 \\
\hline \multirow{9}{*}{$\begin{array}{l}\text { Vitamines } \\
(\mathrm{mg} / 100 \mathrm{~mL})\end{array}$} & Ascorbic acid, $0.1 \mathrm{mg}$ & 108.10 \\
\hline & Ascorbic acid, $0.2 \mathrm{mg}$ & 106.22 \\
\hline & Ascorbic acid, $0.3 \mathrm{mg}$ & 88.83 \\
\hline & Folic acid, $0.05 \mathrm{mg}$ & 93.73 \\
\hline & Folic acid, $0.1 \mathrm{mg}$ & 107.47 \\
\hline & Folic acid, $0.15 \mathrm{mg}$ & 91.83 \\
\hline & Becofort, $0.25 \mathrm{mg}$ & 98.10 \\
\hline & Becofort, $0.5 \mathrm{mg}$ & 81.23 \\
\hline & Becofort, $0.75 \mathrm{mg}$ & 103.73 \\
\hline
\end{tabular}

culture medium of Pichina pastoris lipase, also Lin and Ko (2005) and Xu and Chen, (2006) used vitamin B, at a concentration of $0.1 \%$ in the growth medium of Antrodia cinnamonae.

\section{Lipase production by $M$. racemous in 5 L-stirred tank bioreactor}

In order to design a strategy to improve the large-scale production of $M$. racemosus lipases in this work lipolytic enzyme production in a stirred tank bioreactor has been investigated. The results presented in Figure 6 showed that a typical glucose consumption pattern was observed in which a highly faster glucose uptake has been seen. There was a sharp decrease in glucose concentrations (0.37 \& $0.03 \mathrm{~g} / \mathrm{L}$ after 12 and $24 \mathrm{~h}$, respectively). Nevertheless, the lipase and specific enzyme activities were gradually increased until reaching their maximum values of $1211 \mathrm{U} / \mathrm{mL}$ and $28.0 \mathrm{U} / \mathrm{mg}$ protein after $48 \mathrm{~h}$ with a yield coefficient of about $58.5 \mathrm{U} / \mathrm{g}$ cells/L. Concomitantly, the initial dissolved oxygen (DO) level was rapidly decreased during the initial phase of the fermentation process until reached to $0.7 \%$ after $48 \mathrm{~h}$. Then, it increased gradually until reached its maximum value at the end of the fermentation process and this was accompanied by an increase in the biomass (31.8 $\mathrm{g} / \mathrm{L}$ ). These higher biomass values might have been attributed to the accumulation of the byproducts. In general, when a complex medium is used, by-products are easily produced because the carbon or nitrogen content is not controlled at a suitable level (Ito et al., 2001). Also dissolved oxygen has a significant effect on the lipase production. Thus, it can be proposed that $M$. racemosus fermentation being aerobic, oxygen is necessary to obtain optimum lipase activity (Puthli et al., 2006).

From the aforementioned results, both maximum lipolytic activity and yield coefficient were obtained after $48 \mathrm{~h}$. These values represented 2, 2.3- fold of those obtained using the shake-flask cultivation technique at their optimum conditions $(635.7 \mathrm{U} / \mathrm{mL} ; 8.8 \mathrm{U} / \mathrm{mL} / \mathrm{h})$ respectively.

The enhancement could be attributed to the balanced oxygenation and agitation in the fermentor during the exponential phase and early stationary phase to achieve appropriate cell growth and subsequent improved lipase activity. In the case of stirred bioreactors also, multiple bioreactors are now becoming important due to efficient gas distribution, higher gas phase residence time, increased gas hold-up, superior liquid flow (plug flow) characteristics and lower power consumption per impeller as compared to the single impeller systems resulting into a substantial savings in the operational costs (Puthli et al., 2006). 


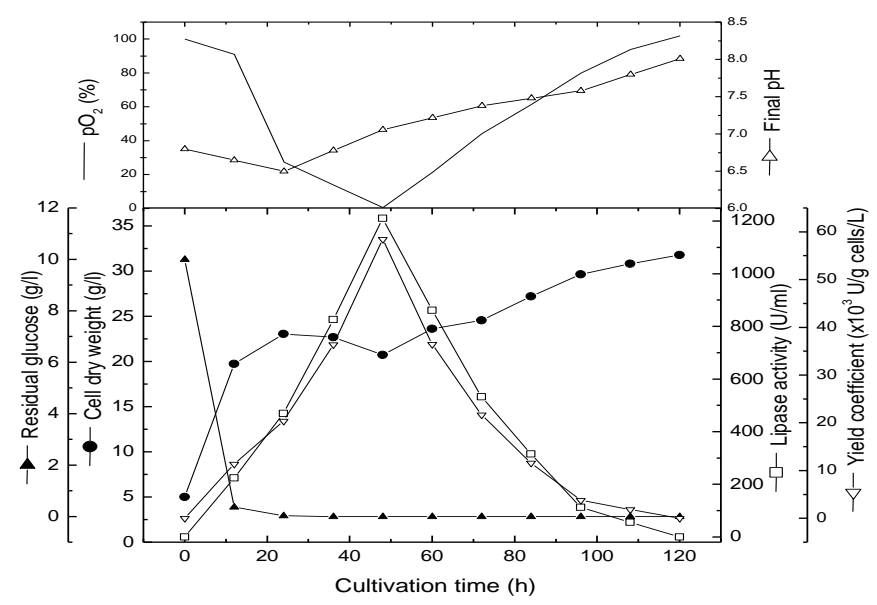

Figure 6: Production of $M$. racemosus lipase in $5 \mathrm{~L}$ stirred tank bioreactor

\section{CONCLUSIONS}

Lipase activity using $5 \mathrm{~L}$ stirred tank bioreactor (1211 $\mathrm{U} / \mathrm{mL}$ ) was improved by 2 folds as compared to shake flask studies (635 U/mL). Moreover, maximum lipase release was attained about $24 \mathrm{~h}$ earlier than in the shake flask experiments. Nevertheless, further research would be necessary to optimize the conditions allowing a stable production of $M$. racemosus lipolytic enzymes in larger scale bioreactors.

\section{REFERENCES}

Abbas, H., Hiol, A., Deyris, V. and Comeau, L. (2002). Isolation and characterization of an extracellular lipase from Mucor sp. strain isolated from palm fruit. Enzyme and Microbial Technology 31, 968-975.

Abdel-Aal, N. A. (1996). Physiological and biochemical studies of lipolytic enzymes produced by microorganisms. M.Sc. Thesis, Faculty of Science, Alexandria University.

Abdel-Fattah, G. M. and Hammad, I. (2002). Production of lipase by certain soil fungi. Optimization of cultural conditions and genetic characterization of lipolytic strains of aspergilli using protein patterns and random amplified polymorphic DNA (RAPD). Journal of Biological Sciences 2, 639-644.

Ahmed, H. M. (2000). Production of lipase enzyme from wastes by microorganisms. M.Sc. Thesis. Faculty of Science, Ain Shams University.

Akhtar, M. W., Mirza, A. Q. and Chughtai, M. I. D. (1980). Lipase induction in Mucor hiemalis. Applied Environmental Microbiology 40, 257-263.

Ammar, M. S. (1983). Influence of organic buffers on lipase production by Bacillus stearothermophilus S.203 in shake cultures. In: Egyptian Social and Applied Microbiology, $5^{\text {th }}$ Conference pp. 88.

Burkert, J. F. M., Mauger, F. and Rodrigues, M. I. (2004). Optimization of extracellular lipase production by Geotrichum sp. using factorial design. Bioresource Technology 91, 77-84.

Chahinian, H., Vanot, G., Ibrik, A., Rugani, N., Sarda, L. and Comeau, L. C. (2000). Production of extracellular lipases by Penicillium cyclopium. Purification and characterization of a partial acylglycerol lipase. Bioscience, Biotechnology and Biochemistry 64, 215-222.

Chander, H., Batish, V. K., Sannabhadti, S. S. and Srinivasan, R. A. (1980). Factors affecting lipase production in Aspergillus wentii. Journal of Food Science 45, 598-600.

Dalmau, E., Montesions, J. L., Lotti, M. and Casas, C. (2000). Effect of different carbon sources on lipase production by Candida rugosa. Enzyme and Microbial Technology 26, 657-663.

Davranov, K. (1994). Microbial lipases in biotechnology: Review. Applied Biochemistry and Microbiology 30, 427-432.

Deabes, M. M. Y., Amra, H. A., Damaty, E. M. and Rowayshed, G. H. (2007). Natural co-occurrence of aflatoxin and cyclopiazonic acid, and their fungi. Production of corn grown in Egypt. In: The $38^{\text {th }}$ Annual Meeting of the Environmental Mutagen Society (EMS), Atlanta, Georgia, USA. pp. 20-24.

Destain, J., Fickers, P., Weekers, F., Moreau, B. and Thonart, P. (2005). Utilization of methyloleate in production of microbial lipase. Applied Biochemistry and Biotechnology 121, 269-277.

Elwan, S. H., Ammar, M. S. and El-Moussallamy, M. K. (1986a). Identity and lipase productivity of Penicillium chrysogenum. Egyptian Journal of Microbiology 21, 143-154.

Elwan, S. H., Ammar, M. S. and Mohawed, S. M. (1986b). Lipases from Aspergillus sydowi, Zentralbl, Microbiology 141, 233-239.

Fernandez, L., Jose, C. S. and Mckellar, R. C. (1990). Repression of Pseudomonas fluorescens 
extracellular lipase secretion by arginine. Journal of Dairy Research 57, 69-78.

Freire, D. M. G., Teles, E. M. F., Bon E. P. S. and SantAnna, G. L. (1997). Lipase production by Penicillium restrictum in a bench-scale fermentor. Effect of carbon and nitrogen nutrition agitation and aeration. Applied Biochemistry and Biotechnology 63, 409-421.

Gupta, N., Sahai, V. and Gupta, R. (2007). Alkaline lipase from a novel strain Burkholderia multivorans: statistical medium optimization and production in a bioreactor. Process Biochemistry 42, 518-526.

Gupta, R., Gupta, N. and Rathi, P. (2004). Bacterial lipases: an overview of production, purification and biochemical properties. Applied Microbiology and Biotechnology 64, 763-781.

Hatzinikolaou, G. D., Macris, B. J., Christakopoulos, P., Kekos, D., Kolisis, N. F. and Fountoukidis, G. (1996). Production and partial characterization of extracellular lipase from Aspergillus niger. Biotechnology Letters 18, 547-552.

Hiol, A., Jonzo, M. D., Rugani, N., Druet, D., Sarda, L. and Comeau, L. C. (2000). Purification and characterization of an extracellular lipase from a thermophilic Rhizopus oryzae strain isolated from Palm fruit. Enzyme and Microbial Technology 26, 421-430.

Ito, T., Kikuta, H., Nagamori, E., Honda, H., Ogino, H., Ishikawa, H. and Kobayashi, T. (2001). Lipase production in two step fed-Batch culture of organic solvent-tolerant Pseudomonas aeruginosa LST-03. Journal of Bioscience and Bioengineering 91, 245250.

Iwai, M. and Tsujisaka, Y. (1984). "Fungal lipase" In: Lipases. Borgstrom, B. and Brockman, H. L. (eds.). Elsevier, Amsterdam, New York, Oxford. pp. 443469.

Jaeger, K. E. and Eggert, T. (2002). Lipases for biotechnology. Current Opinion in Biotechnology 13, 390-397.

Kim, S. S., Kim, E. K. and Rhee, J. S. (1996). Effects of growth rate on the production of Pseudomonas fluorescens lipase during the fed batch cultivation of Escherichia coli. Biotechnology Progress 12, 718722.

Kumar, S., Kikon, K., Upadhyay, A., Kanwar, S. S. and Gupta, R. (2005). Production, purification and characterization of lipase from thermophilic and alkaliphilic Bacillus coagulans BTS-3. Protein Expression and Purification 41, 38-44.

Li, C. Y., Chen, S. J., Cheng, C. Y. and Chen, T. L. (2005). Production of Acinetobacter radioresistens lipase with repeated fed-batch culture. Biochemical Engineering Journal 25, 195-199.

Lin, E. S. and Ko, H. C. (2005). Glucose stimulates production of the alkaline-thermostable lipase of the edible Basidiomycete Antrodia cinnamomea. Enzyme and Microbial Technology 37, 261-265.

Litchfield, C. D. and Prescott, J. M. (1970). Regulation of proteolytic enzyme production by Aeromonas proteolytica. I. Extracellular endopeptidase. Canadian Journal of Microbiology 16, 17-22.

Long, K., Ghazali, H. M., Ariff, A., Ampon, K. and Bucke, C. (1996). Mycelium bound lipase from a locally isolated strain of Aspergilus flavus link: Pattern and factors involved in its production. Journal of Chemical Technology and Biotechnology 67, 157163.

Lowry, O. H., Rosenbrough, N. J., Farr, A. L. and Ranadall, R. J. (1951). Protein measurement with the folin phenol reagent. Journal of Biological Chemistry 193, 265-276.

Maia, M. M. D., Heasley, A., Morais, M. M. C., Melo, E. H. M., Morais, M. A. Jr., Ledingham, W. M. and Filho, J. L. L. (2001). Effect of culture conditions on lipase production by Fusarium solani in batch fermentation. Bioresouce Technology 76, 23-27.

Minning, S., Serrano, A., Ferrer, P., Sola, C., Schmid, R. D. and Valero, F. (2001). Optimization of the highlevel production of Rhizopus oryzae lipase in Pichia pastoris. Journal of Biotechnology 86, 59-70.

Munimbazi, C. and Bullerman, L. B. (1998). Isolation and partial characterization of antifungal metabolites of Bacillus pumilus. Journal of Applied Microbiology 84, 959-969.

Pal, N., Das, S. and Kundu, A. K. (1978). Influence of culture and nutritional conditions on the production of lipase by submerged culture of Aspergillus niger. Journal of Fermentation Technology 56, 593-598.

Pandey, A., Benjamin, S., Soccol, C. R., Nigam, P., Kriger, N. and Soccol, V. T. (1999). The realm of microbial lipases in biotechnology. Biotechnology and Applied Biochemistry 29, 119-131.

Parry, R. M., Chandan, R. C. and Shahani, K. M. (1966). Rapid and sensitive assay for milk lipase. Journal of Dairy Science 49, 356-360.

Passing, H. and Bablok, W. A. (1983). A new biometrical procedure for testing the equality of measurements from two different analytical methods. Journal of Clinical Chemistry and Clinical Biochemistry 21, 709720.

Pokorny, D., Friedich, J. and Cimerman, A. (1994). Effect of nutritional factors on lipase biosynthesis by Aspergillus niger. Biotechnology Letters 16, 363-366.

Prazeres, J. N., Aparecida, J., Cruz, B. and Pastore, G. M. (2006). Characterization of Alkaline lipase from Fusarium oxysporium and the effect of different surfactants and detergents on the enzyme activity. Brazilian Journal of Microbiology 37, 505-509.

Puthli, M. S., Rathod, V. K. and Pandit, A. B. (2006). Optimization of lipase production in a triple impeller bioreactor. Biochemical Engineering Journal 27, 287294.

Rathi, P., Saxena, R. K. and Gupta, R. (2001). A novel alkaline lipase from Burkholderia cepacia for detergent formulation. Process Biochemistry 37, 187192.

Rodriguez, J. A., Mateos, J. C., Nungaray, J., Gonzalez, V., Bhagnagar, T., Rousses, S., Cordova, J. and Baratti, J. (2006). Improving lipase 
production by nutrient source modification using Rhizopus homothallicus cultured in solid state fermentations. Process Biochemistry 41, 2264-2269.

Sarkar, S., Sreekanth, B., Kant, S., Banerjee, R. and Bhattacharyya, B. C. (1998). Production and optimization of microbial lipase. Bioprocess Engineering 19, 29-31.

Sharma, R., Chisti, Y. and Banerjee, U. C. (2001). Production, purifications, characterization and applications of lipases. Biotechnology Advances 19, 627-662.

Silva, W. O. B., Mitidieri, S., Schrank, A. and Vainstein, M. H. (2005). Production and extraction of an extracellular lipase from the entomopathogenic fungus Metarhizum anisopliae. Process Biochemistry 40, 321-326.

Sugiura, M. (1984). "D-Bacterial lipases" In: Lipases. Borgstrom, B. and Brockman, H. L. (eds.). Elsevier, Amsterdam, New York, Oxford. pp. 505-523.

Sugiura, M., Dikawa, T., Hirand, K. and Inukai, T. (1977). Purification. crystallization and properties of triacylglycerol lipase from Pseudomonas fluorescens. Biochimica et biophysica Acta 488, 353-358.

Tan, T., Zhang, M., Wang, B., Ying, C. and Deng, L. (2003). Screening of high lipase producing Candida sp. and production of lipase by fermentation. Process Biochemistry 39, 459-465.

Xu, C. J. and Chen, G. (2006). Purification and partial characterization of a lipase from Antrodia cinnamomea. Process Biochemistry 41, 734-738. 